\title{
Inappropriate Response in Advanced EFL \\ Conversational Exchange
}

\author{
Mohammad Anani \\ Department of English \\ University of Petra, Amman, Jordan \\ P.O Box 852366, Amman, Jordan \\ E-mail:manani@uop.edu.jo
}

Received: April 11, 2013 Accepted: May 2, 2013 Published: May 5, 2013

doi:10.5296/ijele.v1i3.3639 URL: http://dx.doi.org/10.5296/ijele.v1i3.3639

\begin{abstract}
Advanced Arab learners of English experience difficulty in responding appropriately within a given situation. In a lively conversation, e.g. a business agreement over a business desk, a formal debate, polite requests, interviews, etc. the devices and strategies used, by and large, draw upon Arabic linguistic and cultural sources. As a result, the overall performance is adversely affected and mutual intelligibility is impeded. This study therefore focuses on utterances produced or reproduced by the other party (the listener) in a conversational exchange.

The objectives of this study is to highlight the type of response an advanced Arab learner selects in some typical English conversational interchanges so that similarities and /or differences between L1 and L2 are singled out. To achieve this end, two groups of advanced Arab learners of English have been selected. The first represents 'fluent' speakers of English and the second, the non-fluent' represents students who study English for instrumental purposes at Petra University.
\end{abstract}

Keywords: inappropriate response conversational exchange L1/L2 differences 


\section{Ml Macrothink \\ International Journal of English Language Education \\ ISSN 2325-0887 \\ 2013, Vol. 1, No. 3}

\section{Introduction}

\subsection{Interest in the 'ideal' Sentence}

In most excellent English teaching grammars that teachers of English have used for so long, the listeners' expressions in response to the other participant/s in a conversational exchange have been assigned a minor position at the expense of more comprehensive linguistic description given to the formal exponents of the "ideal" sentence. (Cf. C. F. Hockett (1958). A. A. Hill (1958), Sledd (1959, P. Roberts (1956), Whitehall (1960) and R. B. Long (1961). Although grammar textbook writers give prominence to the description of sentence types formally and notionally, they show very little interest in the description of the linguistic features of response utterances. Interest is likewise diverted from the function of the different 'operators' occurring in response positions.

\subsection{Acquisition of Appropriate Response}

In learning English as a second language, knowing whether a response to a given stimuli is appropriate at all, as well as the proper linguistic form to express it is part of the communicative competence learners need to acquire. For example, in a situation in which an English native speaker offers his Arab host some biscuits at a tea party, the Arab participant is most likely to say in the first instance 'no, thank you' expecting the invitation 'to have biscuits' to be repeated more than once as a sign of respect. If no repetition has been done, the recipient will be embarrassed. On the other hand, this cultural norm of behavior, on the part of the Arab recipient, may cause misunderstanding and lead to communicative failure.

\subsection{Linguistic Enquiry: 'function'}

A comprehensive description of response expressions involves many forms of linguistic enquiry: phonological, syntactic, lexical and functional. This study is limited to the last. Attention will be paid to the relevant factors which might have led to select one or the other of variants so that appropriate or inappropriate responses are highlighted.

\section{Identification of Response Expressions}

\subsection{Corpus of Study}

In order to identify English response expressions, recordings of texts from (Jeremy Harmer's book Advanced Speaking Skills, Longman, 1978) have been made and were presented to students studying English at Petra University, Amman, Jordan to find out the type of spontaneous response they usually give in the typical situational settings cited.

\subsection{Types of Response}

The table below shows the two types of response and the language function with which they are associated: Column 1 represents sentence-type, column 2 represents the linguistic function, i.e. what language is used for; column 3 represents L1 appropriate response-type; column 4 represents $\mathbf{L} 2$ inappropriate response -type: 
Table 1.

\begin{tabular}{|c|c|c|c|}
\hline $\begin{array}{l}\text { Sentence } \\
\text { type }\end{array}$ & Function & L1 Response type & L2 Response type \\
\hline \multirow[t]{10}{*}{ Statements } & 1. Stating Likes: & 1.1 agreeing: & \\
\hline & I like ice-cream; & (so do I) & \\
\hline & I am keen on pop music & (so am I) & (me too) \\
\hline & & 1.2 disagreeing: & \\
\hline & & (oh, do you) & (Is that true?) \\
\hline & & (oh, are you) & (Is that true?) \\
\hline & 2. Stating Dislikes: & & \\
\hline & $\begin{array}{l}\text { I am not keen on pop } \\
\text { music }\end{array}$ & $\begin{array}{l}\text { 2.1. agreeing: } \\
\text { (neither am I) }\end{array}$ & (not me too) \\
\hline & & $\begin{array}{l}\text { 2.2 disagreeing: } \\
\text { (oh, aren't you) }\end{array}$ & (Is that true") \\
\hline & $\begin{array}{l}\text { 3.enquiring about news: } \\
\text { (e.g. I hope everything is } \\
\text { going well in your new } \\
\text { flat) }\end{array}$ & $\begin{array}{l}\text { 3.1. reacting to good } \\
\text { news: } \\
\text { (e. g What marvelous } \\
\text { news) } \\
\text { 3.2.reacting to bad } \\
\text { news: } \\
\text { (e.g. how awful } \text { ) }\end{array}$ & $\begin{array}{l}\text { (perfect, [tamaam]. } \\
\text { Great) } \\
\text { [?amma musiibah] } \\
\text { 'What a misfortune' }\end{array}$ \\
\hline & $\begin{array}{l}\text { 4. making a suggestion: } \\
\text { (e.g. We could go on a } \\
\text { tour) }\end{array}$ & $\begin{array}{l}\text { 4.1. agreeing: } \\
\text { (e.g. That sounds like } \\
\text { a good idea) } \\
\text { 4.2. disagreeing; } \\
\text { (That's not possible) }\end{array}$ & $\begin{array}{l}\text { (o.k. let's go) } \\
\text { [yalla, xalliina } \\
\text { nruuH] } \\
\text { No, no. }\end{array}$ \\
\hline & $\begin{array}{l}\text { 5. offering a choice: } \\
\text { (e.g. We could either } \\
\text { watch t.v. or listen to the } \\
\text { radio. Which would you } \\
\text { prefer> }\end{array}$ & $\begin{array}{l}\text { 5.1. positive } \\
\text { preference: } \\
\text { (I'd rather watch t.v.) }\end{array}$ & (I like to watch t.v.) \\
\hline & & $\begin{array}{l}\text { 5.2. negative } \\
\text { preference; } \\
\text { (e.g. I don't fancy } \\
\text { either ) } \\
\end{array}$ & ( I don't like both) \\
\hline
\end{tabular}




\begin{tabular}{|c|c|c|c|}
\hline & $\begin{array}{l}\text { 6. expressing personal } \\
\text { opinion: } \\
\text { (e.g. from my point of } \\
\text { view money isn't } \\
\text { everything): }\end{array}$ & $\begin{array}{l}\text { 6.1. agreeing: } \\
\text { (e.g. I'd go along with } \\
\text { you/ I couldn't agree } \\
\text { more) } \\
\text { 6.2. disagreeing: } \\
\text { (e.g. Do you really } \\
\text { think so? }\end{array}$ & (I agree 100\%) \\
\hline \multirow[t]{2}{*}{ Question } & $\begin{array}{l}\text { 7. extending invitations: } \\
\text { (e.g. Would you like to } \\
\text { visit Petra?) }\end{array}$ & $\begin{array}{l}\text { 7.1. accepting: } \\
\text { (e.g. That sounds } \\
\text { very nice. Thanks. }\end{array}$ & (yes, I like very much \\
\hline & & $\begin{array}{l}\text { 7.2. } \text { refusing: } \\
\text { (I can't, I'm afraid) }\end{array}$ & No, no, I can't) \\
\hline \multirow[t]{3}{*}{ Question } & $\begin{array}{l}\text { 8. asking for opinions: } \\
\text { (e.g. What do you think } \\
\text { of the latest price rise? }\end{array}$ & $\begin{array}{l}\text { 8.1.complying: } \\
\text { (e.g. I think it is } \\
\text { necessary) } \\
\text { 8.2. non-complying: } \\
\text { (e.g. Frankly, it's } \\
\text { intolerable) }\end{array}$ & $\begin{array}{l}\text { My opinion; it is } \\
\text { necessary. } \\
\text { To tell you the truth; } \\
\text { it's intolerable. }\end{array}$ \\
\hline & $\begin{array}{l}\text { 9. criticizing someone: } \\
\text { (e.g I'm sick and tired of } \\
\text { George throwing plastic } \\
\text { bags around.) }\end{array}$ & $\begin{array}{l}\text { 9.1. agreeing: } \\
\text { (Yes, he's a problem, } \\
\text { isn't he?) } \\
\text { 9.2. disagreeing: } \\
\text { (e.g. I can't say I have } \\
\text { noticed) }\end{array}$ & $\begin{array}{l}\text { (Frankly, he doesn't } \\
\text { behave himself) } \\
\text { (He isn't that bad; not } \\
\text { To that degree) }\end{array}$ \\
\hline & $\begin{array}{l}\text { 10. apologies: } \\
\text { (e.g. I'm sorry I'm late) }\end{array}$ & $\begin{array}{l}\text { 10.1. accepting } \\
\text { apologies: } \\
\text { (e.g. not to worry) } \\
\text { 10.2. reacting to } \\
\text { apologies } \\
\text { unhappily: } \\
\text { (e.g. oh, dear ; oh no) }\end{array}$ & $\begin{array}{l}\text { (O.K. but don't do it } \\
\text { again) } \\
\text { (May God give us } \\
\text { patience) }\end{array}$ \\
\hline
\end{tabular}

\section{Response Testing}

This study assumes that response sentences are sources of difficulty to the advanced Arab learner. There is a tendency for an Arab learner to react inappropriately selecting strategies and devices that are considered to be immediate reproductions of the Arabic translation equivalents. In order to corroborate initial observation and provide a method for studying the problem, 12 conversational exchanges are recorded in a recording sound proof room of the Digital Language Lab - the University of Petra. Each conversational exchange is followed by a test comprising four variant response utterances. Subjects taking the test are required to 


\section{Macrothink \\ International Journal of English Language Education \\ ISSN 2325-0887 2013, Vol. 1, No. 3}

circle what they think is the most appropriate response in the situation.

The test, comprising 12 items,(see Appendix) was presented to two groups of advanced learners of English at Petra University, Amman. The first group consists of 10 fluent speakers who speak English in a near native fluency. They lived and were educated part of their pre-university education in the United States. The second group consists of 70 non-fluent advanced learners who passed the English Proficiency Exam. The results of the test are shown below:

\section{Results}

\subsection{Fluent Speakers}

Test item: $\quad$ Percentage of correct appropriate responses

$\begin{array}{ll}1 . & 100 \% \\ 2 . & 100 \% \\ 3 . & 100 \% \\ 4 . & 83.3 \% \\ 5 . & 83 \% \\ 6 . & 100 \% \\ 7 . & 100 \% \\ 8 . & 100 \% \\ 9 . & 100 \% \\ 10 . & 100 \%\end{array}$

\subsection{Non-Fluent Speakers}

Test item: $\quad$ Percentage of correct appropriate responses

1 .

2.

3.

4.

5.

6.

7.

8.

9.

10.

11.

12.

13.
$94.3 \%$

$51.4 \%$

$50 \%$

$45 \%$

$44.3 \%$

$77.1 \%$

$77.1 \%$

$55.7 \%$

$64.3 \%$

$32 / 9 \%$

$67.1 \%$

$77.1 \%$

\subsection{Proficiency and Ability to Respond}

There appears to be positive correlation between student proficiency and ability to respond 


\section{Macrothink}

appropriately to the purpose language is put to use, i.e. language function. The higher percentage obtained by fluent speakers indicate higher ability to organize accurate response which involves an unconscious knowledge of L2 subtle cultural norms. Knowing the appropriate response as well the linguistic strategies employed to achieve the speaker's purpose is part of the communicative competence non-fluent learners need to acquire.

\subsection{Socio-pragmatic' Failure}

Failure to respond appropriately to item 10 in the sample population surveyed may be attributed to "sociopragmatic' failure (Cf. Holms. J, 1987.) For example, returning goods to shops after a lapse of time in the Arab culture is normally unacceptable. The likely response to a complaint lodged by a customer when he returns goods purchased is "Things bought here cannot be returned," in contrast with "There is nothing we can do about it, I'm afraid", which is the appropriate response selected by the fluent group (100\%).

Accepting or rejecting apologies and the linguistic devices used to express them are somewhat different from those of Arabic in certain situations. For example, when a car accident takes place, an apology may be rejected:

A. I seem to have backed my car into yours. I'm really sorry.

B. (Arabic R)You are to blame. You should've opened your eyes. I'll call the police.

\subsection{Different Linguistic Strategies: Question Tags \& Operators}

Another important factor contributing to the low percentages of items 2, 3, is due to difficulty encountered by the use of question tags. or a dependent clause containing a 'code operator':

\section{A. I can't stand violent films}

B. (disagreeing) Oh, can't you.

The use of question tags in response sentences or "code" operators occurring in response positions is avoided by Arab interlocutors. The linguistic strategy adopted when the situation dictates an appropriate response using a tag or a code operator is a selection of an Arabic lexical "echo" word equivalent, e.g. in a situation in which Sami was badly hurt in a car accident:

\section{Utterance \\ L1 appropriate $R$ \\ L2 inappropriate $\mathbf{R}$}

Isn't it sad about Sami? Yes, terrible, isn't, it? Yes, very sad

What a good thing

his wife wasn't with him. Yes, wasn't it?

Yes, a good thing 


\section{Macrothink \\ International Journal of English Language Education \\ ISSN 2325-0887 \\ 2013, Vol. 1, No. 3}

\section{Pedagogic Implications}

Although the results may not necessarily reflect any "true" level of ability, they may well have significant implications for, e.g. the identification and solving key problems currently experienced by Arab interlocutors engaged in a conversational exchange with native speakers. Furthermore; knowledge of the conditions that determine choice of one or more variants of response is absolutely necessary for ease of communication. For example, conditions of choice are not limited to but would include context of situation: one demanding formal or emphatic speech, or the choice may be determined by "attitudes" appropriate to permanent relationships such as "parent to child", "secretary to boss"; or sometimes choice is governed by cultural norms observed in 'politeness', 'bluntness', "formality" and "intimacy." The foregoing analysis will hopefully provide EFL curriculum designers with an approach to identify problem areas in handling specific forms of English at the 'minor' level, and to focus their attention on the selection of language forms appropriate to particular functions or uses of language.

\section{References}

Fries, C. C. (1987). The Structure of English. New York: Harcourt Brace, Harmer.

Hill, A. A. (1958). An Introduction to Linguistic Structures Harcourt Brace.

Hockett, C. F. (1988). A Course in Modern Linguistics. New York: Macmillan.

Holmes , Janet. (1987). Teachers and Students Learning About Compliments. Tesol Quarterly, 21(3), 523-546.

Lee, W. R. (1955-56). English Introduction: A New Approach. Lingua, 346-347.

Long, R. B. (1961). The sentence and Its Parts. Chicago: The University of Chicago Press.

Sledd. (1959). Short Introduction to English Grammar. Chicago: Scott, Foresman \& Company.

\section{Appendix}

\section{Test Items:}

1. It was Sami's fist time to visit Cairo, His friend Ahmad, who lived there, decided to take him out and show him the rest of the city.

Sami: Cities are very noisy, aren't they?
Ahmad: (agreeing)
(a) Yes, they are.
(b) No, they aren't.
(c) Correct.
(d) Correct, $100 \%$. 


\section{Macrothink

2. David and Carol are having lunch together and giving their opinions on what type of movies they like and dislike.

David: I am rather keen on going to horror films.

Carol: (agreeing)
(a) I, also.
(b) So do I.
(c) So am I.
(d) Correct.

3. Suzan and Jane have just met each other at an art exhibition. They both told each other about their interest in classical music.

Suzan: Personally, I find classical music extremely classical.

Jane: (disagreeing) (a) Your speech is not correct.

(b) Oh, are you?

(c) You are wrong.

(d) Oh, do you?

4. Nancy meets Abraham on the stairs near his office. Abraham is clearly not well. Nancy: You're not looking very well.
Abraham: (agreeing)
(a) I'm feeling pretty awful, actually.
(b) Yes, I feels tired.
(c) No, not at all.
(d) No, not really.

5. Suzan hears from her friend that Moses' grandmother has passed away. Suzan decides to call and tell her she is sorry for his loss.

Suzan: I hear your grandmother has just died. I'm so sorry for your loss.

Moses:
(a) All people die.
(b) I'm sorry too.
(c) It's ok, not to worry.
(d) She is dead already. 


\section{Macrothink

6. Ben: I hear Joseph just passed his final exam.

Sami:

(a) What marvelous news!

(b) It's strange.

(c) It's expected.

(d) He doesn't deserve.

7. John: Have you heard about John's accident? He hit the back of a lorry!

Peter: Yes, it's awful,

(a) Isn't it?

(b) Is it?

(c) Really?

(d) It is?

8. Tamara is a secondary school teacher at Petra Secondary School. She and the school principal both agree that Samir is very intelligent.

Tamara: As far as I am able to judge, I think Faisal is very intelligent.

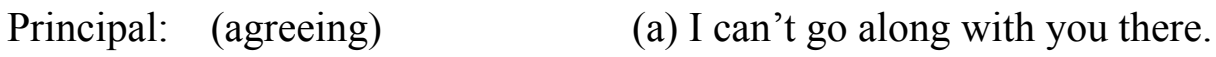

(b) I couldn't agree more!

(c) Is he?

(d) I can't say I have noticed.

9. Katherine and Nichole are at a restaurant. They both happen to be interested in playing tennis.

Katherine: Are you into playing tennis?

Nichole:

(a) Correct!

(b) I do, actually.

(c) I am, actually.

(d) Not at all! 


\section{Macrothink}

10. David has recently bought a radio. The radio is not working. He goes back to the shop and complains to the shop assistant.

David: The radio I have at your shop is not working. Could I return it?

Shop assistant:

(a) Things bought cannot be returned.

(b) You must have played with it.

(c) There is nothing we can do about it.

(d) It must be the factory's fault.

11. Sally: I am sick and tired of students smoking in the corridor.

Tala: (agreeing) $\quad$ (a) Oh, come on! Smoking isn't that bad.

(b) I am sick, too.

(c) Yes, it is a problem. Isn't it?

(d) Really? I can't say I've noticed.

12. Rand is visiting her aunt. In the dining room, she admires her aunt's vase. Unfortunately, she breaks it while looking at it.

Rand: I had no intention of breaking it.

Her aunt: (accepting her apology)
(a) It's alright. These things happen.
(b) This vase is very expensive!
(c) It's great loss to me. You must pay for it.
(d) Oh, God!

\section{Copyright Disclaimer}

Copyright reserved by the author(s).

This article is an open-access article distributed under the terms and conditions of the Creative Commons Attribution license (http://creativecommons.org/licenses/by/3.0/). 